\title{
Not Dead Yet: The Spectre of Nursing Human Resource Shortages
}

Kathleen MacMillan, RN, PhD

Professor and Director, School of Nursing, Dalhousie University

Halifax, NS

Since the late 1990s, the nursing shortage has occupied the attention of the profession, policy makers and employers (CNA 2009; WHO 2006). In this Special Issue of the Canadian Journal of Nursing Leadership, we have an opportunity to revisit the problem of nursing human resources from the standpoint of labour mobility. I say "revisit" because the problem has been sleeping in Canada, as many decision-makers and policy makers seem to believe that we have addressed this by increasing the number of nursing seats in undergraduate nursing programs.

While we have been successful in turning up production, serious concerns remain with transition to work for new graduates; high attrition rates from the profession in the first two to three years following graduation; and looming retirements of the baby boomer cohort. One aspect of nursing human resources that has been understudied is labour mobility and factors that influence nurses to move from one place to another during their careers. It is very timely to examine this poorly understood factor in nursing supply, given projected nursing shortages in the United States and Canada within this decade, and the recent decision to adopt the American NCLEX examination for entry to practice in place of the Canadian CRNE, effective 2015 (NCSBN 2011). We may be moving into a new period of heightened concern about the supply of nurses in Canada.

While the majority of nurses still stay close to the place from which they complete their initial nursing education, the younger generation of nurses is more global in orientation, and one of the reported attractions for choosing a nursing career in the first place is the potential for mobility. Papers included in this issue explore factors that influence nurses to relocate, both within Canada and beyond our borders to the US, so that we may have a better understanding of what motivates mobility and how this information might be utilized to promote retention of Canadian nurses.

In this Special Issue, McGillis Hall, Peterson, Price and Lalonde report on the migration of nurses from Canada to the US - a trend that has increased since the 1990s. The investigators report that almost half of the Canadian educated nurses in this study moved to the US in search of full-time work after they had been unable to secure 
full-time employment in Canada. Further, the level of job satisfaction of these nurses suggests that return to Canada is unlikely.

A study of career decisions made by Canadian-educated, early career nurses who are working in the US reports that factors related to compensation, nurse-patient ratios and opportunities for career development influenced career decisions (Petersen et al.). In particular, nurses identified agency support for continuing education and professional development as areas where Canadian employers were not competitive.

The focus of the papers by McGillis Hall, Peterson, Price and colleagues and Andrews and colleagues shifts to internal migration within Canada. The authors assert that we should be paying closer attention to factors that contribute to internal migration in order to develop realistic recruitment and retention strategies that will at least keep nurses from leaving Canada. Again, almost one-third of study participants reported that they relocated because they were unable to find work in the province in which they originally graduated, but many hoped to be able to return to their home jurisdiction. Many respondents also described challenges with obtaining registration in another Canadian jurisdiction compared to relative ease outside Canada.

Support for, and access to, continuing education may play a role in nurse labour mobility (Lalonde et al.). Canadian nurses value continued learning but identify financial and scheduling barriers to participation. Lack of access to accredited continuing education programs is highlighted.

A study of the experiences of nurses who have moved between the provinces and territories in Canada for work (Price et al.) uncovers that the decision to move is influenced by the desire to provide high-quality direct patient care and is related to professional socialization. Participants described that they chose a career in nursing specifically to work directly with patients, and felt that changes in nursing work are taking them away from the bedside and creating dissatisfaction with their jobs.

Practical nurse mobility is the subject of the paper by Harris and colleagues, in which they identify three primary motivators for LPN migration. Just like their RN colleagues, LPNs valued opportunities for career and educational advancement, but respondents also reported that scope of practice and professional respect and recognition were influencing factors. This finding suggests that LPNs have unique viewpoints compared to their RN colleagues and should be another focus for future research.

Nelson's paper describes the impact of global trends on nurse migration through examination of economic policies and trade agreements designed to support movement of goods and services. A post-modern phenomenon, these agreements are affecting the movement of skilled labour in many sectors, including nurses. Nelson 
posits that poor capacity for absorption of new nursing graduates within Canada will further increase losses to competitor markets such as the US. While fully engaging in global trade negotiations and agreements, Canada's Agreement on Internal Trade and Tariffs is still being implemented and thus has an impact on internal nurse mobility. In contrast, within the European Common Market (ECC), there is between-state recognition for seven health professions, including nursing, among the 27 members, and a single European Professional Card is being proposed (EC 2011).

The potential impact of these papers on policy and decision-makers is the subject of the paper by Foster and colleagues. Over the decade following release of A Nursing Strategy for Canada (Health Canada 2004), recruitment and retention strategies were implemented at all levels of government and within the profession, and this has resulted in a growth in numbers of new graduates and retention of nurses. However, the landscape has shifted since these policies were implemented. For example, once again new graduates are experiencing challenges in securing full-time employment upon graduation. Shortages are beginning to emerge, but they are primarily in areas of specialty practice such as, for example, critical care, the OR and mental health, areas where new graduates are poorly prepared to practise immediately on completion of their basic programs. Further, employers express concern about the proportion of new graduates that can be absorbed at one time without compromising overall team practice competency. Effective partnerships among employers, educators and policy makers will be required to meet these emerging challenges.

While the policies that have been introduced in Canada to increase the number of nurses have demonstrated success, this does not mean that the nursing shortage crisis is over or that we can rest on our recent achievements. Historically, governments have not paid much attention to the movement of individuals to seek the work of their choice. But significant shifts in out-migration can have a major impact on the health sector and on our economy. If new graduates in large numbers choose to migrate to the US to secure full-time employment, attractive career opportunities and satisfactory professional practices, our efforts to date could be wasted, and the spectre of shortage could emerge as a very real problem within the next very few years.

We live in a global world and we participate in a global economy. We need to understand personal and professional motivation, the impact of trade agreements, and the movement of goods and services (including labour) to formulate effective policies and strategies to recruit and retain health professionals. The nursing shortage is not dead yet, and we ignore it at our peril. 


\section{References}

Andrews, G., L. McGillis Hall, J. Peterson, S. Price, M. Lalonde, A. Harris and S. MacDonald-Rencz. 2013. "Mapping Nurse Mobility in Canada with GIS: Career Movements from Two Canadian Provinces." Canadian Journal of Nursing Leadership 26(Special): 41-50. <http://www.longwoods. com/content/23249>.

Canadian Nurses Association (CNA). 2009. Tested Solutions for Eliminating Canada's Registered Nurse Shortage. Ottawa: Author.

Foster, B., S. MacDonald-Rencz and L. McGillis Hall. 2013. "Migration and Mobility: Informing Nursing Health Human Resources Retention and Recruitment Policy." Canadian Journal of Nursing Leadership 26(Special): 87-94. <http://www.longwoods.com/content/23255>.

European Commission (EC). 2011. Modernising the Professional Qualifications Directive. Retrieved January 2, 2013. <http://eur-lex.europa.eu/LexUriServ/LexUriServ.do?uri=COM:2011:0367:FIN:en:PDF>.

Harris, A., L. McGillis Hall, J. Peterson, S. Price, M. Lalonde, G. Andrews and S. MacDonald-Rencz. 2013. "LPN Perspectives of Factors that Affect Nurse Mobility in Canada." Canadian Journal of Nursing Leadership 26(Special): 70-78. <http://www.longwoods.com/content/23252>.

Health Canada. 2004. A Nursing Strategy for Canada: Report of the Advisory Committee on Health Human Resources. Retrieved January 18, 2013. <http://www.hc-gc.ca/hcs-sss/pubs/nursinfirm/2000-nurs-infirm-strategy >.

Lalonde, M., L. McGillis Hall, J. Peterson, S. Price, G. Andrews, A. Harris and S. MacDonald-Rencz. 2013. "Support and Access for Nursing Continuing Education in Canadian Work Environments." Canadian Journal of Nursing Leadership 26(Special): 51-60. <http://www.longwoods.com/ content $/ 23250>$.

McGillis Hall, L., J. Peterson, S. Price, G. Andrews, M. Lalonde, A. Harris and S. MacDonald-Rencz. 2013. "I Was Never Recruited: Challenges in Cross-Canada Nurse Mobility." Canadian Journal of Nursing Leadership 26(Special): 29-40. <http://www.longwoods.com/content/23248> .

McGillis Hall, L., J. Peterson, S. Price, M. Lalonde and S. MacDonald-Rencz. 2013. "Stemming the Flow of Canadian Nurse Migration to the US." Canadian Journal of Nursing Leadership 26(Special): 8-19. $<$ http://www.longwoods.com/content/23246>.

National Council of State Boards of Nursing (NCSBN). 2011 (December 8). NCSBN and Pearson VUE to bring NCLEX-RN Examination to Canada. News release. Retrieved January 2, 2013. <https:// www.ncsbn.org/3048.htm>.

Nelson, S. 2013. "Global Trends, Local Impact: The New Era of Skilled Worker Migration and the Implications for Nursing." Canadian Journal of Nursing Leadership 26(Special): 82-86. <http://www. longwoods.com/content/23254>.

Peterson, J., L. McGillis Hall and S. Price. 2013. "The Experiences of Canadian-Educated Early Career Nurses Who Practise in the US." Canadian Journal of Nursing Leadership 26(Special): 20-28. $<$ http://www.longwoods.com/content/23247>.

Price, S., L. McGillis Hall, J. Peterson, M. Lalonde, G. Andrews, A. Harris and S. MacDonald-Rencz. 2013. "Factors That Influence Career Decisions in Canada's Nurses." Canadian Journal of Nursing Leadership 26(Special): 61-69. <http://www.longwoods.com/content/23251>.

World Health Organization (WHO). 2006. Working Together for Health: The World Health Report 2006. Geneva: Author. 